\title{
Correlation of SATB1 overexpression with the progression of human rectal cancer
}

\author{
Wen-Jian Meng, Hui Yan, Bin Zhou, Wei Zhang, Xiang-Heng Kong, Rong Wang, Lan Zhan, \\ Yuan Li, Zong-Guang Zhou and Xiao-Feng Sun
}

\section{Linköping University Post Print}

N.B.: When citing this work, cite the original article.

The original publication is available at www.springerlink.com:

Wen-Jian Meng, Hui Yan, Bin Zhou, Wei Zhang, Xiang-Heng Kong, Rong Wang, Lan Zhan, Yuan Li, Zong-Guang Zhou and Xiao-Feng Sun, Correlation of SATB1 overexpression with the progression of human rectal cancer, 2012, International Journal of Colorectal Disease, (27), 2, 143-150.

http://dx.doi.org/10.1007/s00384-011-1302-9

Copyright: Springer Verlag (Germany) http://www.springerlink.com/

Postprint available at: Linköping University Electronic Press http://urn.kb.se/resolve?urn=urn:nbn:se:liu:diva-75469 


\section{Title page}

\section{Title:}

Correlation of SATB1 overexpression with the progression of human rectal cancer

\section{Running title:}

Elevated expression of SATB1 in human rectal cancer

\section{Authors:}

Wen-Jian Meng • Hui Yan • Bin Zhou . Wei Zhang • Xiang-Heng Kong .

Rong Wang . Lan Zhan • Yuan Li . Zong-Guang Zhou . Xiao-Feng Sun

W.-J. Meng • H. Yan . W. Zhang • X.-H. Kong • Z.-G. Zhou ( $\varangle)$

Department of Gastrointestinal Surgery, West China Hospital, Sichuan University,

37 Guo Xue Xiang, Chengdu 610041, China

e-mail address: zhou767@163.com

Tel: +86 28 81654035; Fax: +8628 81654035

W.-J. Meng · H. Yan B. Zhou • W. Zhang • X.-H. Kong ·

R. Wang · L. Zhan . Y. Li . Z.-G. Zhou • X.-F. Sun

Institute of Digestive Surgery and Organ Microcirculation, West China Hospital,

Sichuan University, Chengdu 610041, China

Y. Li

Department of Pediatric Surgery, West China Hospital, Sichuan University, Chengdu 610041, China

Y. Li • Z.-G. Zhou

National Key Laboratory of Biotherapy of West China Hospital, Sichuan University, Chengdu 610041, China

X.-F. Sun

Department of Oncology, Linköping University, Linköping, Sweden 


\begin{abstract}
Background and aims To date, the association between special AT-rich sequence-binding protein 1 (SATB1) and colorectal cancer (CRC) has not been reported. This study was aimed at investigating the expression and potential role of SATB1 in human rectal cancers.

Methods Ninety-three paired samples of rectal cancer and distant normal rectal tissue were analyzed by quantitative real-time PCR (qRT-PCR) and immunohistochemistry (IHC), and the correlations between SATB1 expression and clinicopathological parameters were evaluated. The expression profiles of SATB1 were also investigated in a panel of five human colon carcinoma cell lines.

Results The general level of SATB1 mRNA in rectal cancer tissues was statistically significantly higher than that in normal mucosa $(P=0.043)$. The rate of positive SATB1 protein expression in rectal cancers $(44.1 \%)$ was significantly higher than that in normal tissues $(25.8 \%)$ by IHC analysis $(P=$ 0.009). Overexpression of SATB1 mRNA was more predominant in patients with earlier onset of rectal cancer $(P=0.033)$. SATB1 expression correlated with invasive depth and tumor node metastasis (TNM) stage at both protein and mRNA levels $(P<0.05)$. Furthermore, SATB1 expression in the poorly metastatic KM12C cells was significantly lower than the highly metastatic KM12SM and KM12L4A cells and higher than the HCT116 and SW480 cells $(P=0.001)$. These results were further confirmed by Western blotting.

Conclusion Our results indicate that SATB1 may play an important role in the progression of human rectal cancer, which represents a possible new mechanism underlying CRC.
\end{abstract}

Keywords Special AT-rich sequence-binding protein 1 . Human rectal cancer . Quantitative real-time PCR . Immunohistochemistry . KM12C cell lines 


\section{Introduction}

Colorectal cancer (CRC) is one of the most common gastrointestinal tumors and the second leading cause of cancer-associated deaths in the world. The incidence of CRC in China is lower than that in the Western world but has been increasing in recent years [1]. Although advanced methods of diagnosis and treatment have been employed over the last few decades, the overall survival rate of patients with CRC has not improved markedly. Distant metastasis is the most common cause of death in CRC patients, although little is known about the exact mechanisms underlying the metastasis of this type of cancer. Therefore, identifying key regulators and their functions in colorectal metastasis will be vitally important for the future development of effective interventions.

Special AT-rich sequence-binding protein 1 (SATB1) is a thymocyte-specific matrix association region (MAR)-binding protein that links specific DNA elements to its cage-like network [2]. It facilitates formation of an open chromatin structure and participates in the regulation of hundreds of genes. In recent years, a number of studies have suggested that it plays major roles in T-cell development, early erythroid differentiation, homeostasis and response to physiological stimuli [3-6]. In addition to discoveries of these physiological roles, SATB1 has recently attracted considerable attention due to its high expression in various types of malignant tumors, such as breast cancer, gastric cancer and laryngeal cancer, which suggest a crucial role in promoting tumor invasion and metastasis [7-10]. A recent study showed that the expression of SATB2, a closely related homolog of SATB1, is associated with metastasis and poor prognosis in CRC [11]. However, the relationship between SATB1 and CRC has not been reported.

In this study, we investigated the prevalence and clinicopathological implications of SATB1 expression in 93 patients with primary rectal cancer. Furthermore, by using quantitative real-time PCR (qRT-PCR) and Western blotting analysis, we confirmed the results in a panel of colon cancer cell lines. The results of this study indicate that SATB1 expression correlates with the invasiveness of tumor cells and may be a new pathway marker for the progression of CRC.

\section{Materials and Methods}


Tissue specimens

One hundred paired samples of rectal cancer and distant normal rectal tissues were obtained from 105 inpatients who underwent surgeries at the West China Hospital of Sichuan University (Sichuan, China) from February to November 2009. The patients received no chemotherapy or radiation before the operation. The rectal cancer and paired normal rectal tissues were allocated into the cancer and control groups, respectively. Parts of each sample were fixed in formalin and embedded in paraffin wax. Tumor histotype and grading were defined according to the recommendations of the World Health Organization for the histological typing of CRC. All cases were staged using the 7th edition of the Cancer Staging Manual of the American Joint Committee on Cancer (AJCC) [12]. Differentiation of low grade tumors were good and moderate, while that of high grade tumors were poor and unspecified. Histopathological examinations were conducted by the Pathological Research Institution of West China Hospital. Carcinoma cells were observed in all cancer samples under an optical microscope. Informed consent was provided by all subjects, and approval was obtained from the Regional Ethics Committee. Of 105 cases, 12 were excluded because of tissue unavailability or incomplete medical records, resulting in a total of 93 eligible cases.

\section{Cancer cell lines}

Human colon carcinoma cell lines KM12C, KM12SM and KM12L4A were kindly provided by Isaiah Fidler (M.D. Anderson Cancer Center, Houston, TX, USA). The parental cell line KM12C was originally established from a primary Dukes B2 colon carcinoma. Cells from this cell line were repeatedly passaged in athymic mice by injection into the cecum and spleen, and two new cell lines, KM12SM and KM12L4A, were isolated with high metastatic potential. The cell lines were maintained in Eagle's MEM medium supplemented with 10\% heat-inactivated fetal bovine serum, sodium pyruvate, vitamins and a cocktail of penicillin and streptomycin at $37^{\circ} \mathrm{C}$ in $5 \%$ carbon dioxide. Cells growing in the exponential phase were harvested at approximately $80 \%$ confluence. The HCT116 and SW480 cell lines obtained from our laboratory were used as controls and grown in standard culture conditions. 
Primers and probes

The primers and probes designed for qRT-PCR were purchased from TNXK Biotechnology Co., Ltd. (Beijing, China). The probes for SATB1 and $\beta$-actin (reference gene) were 5'FAM-CCAGCGTAACAGCTCGCACAAC-TAMRA-3' and 5'FAM-TCAACACCCCAGCCATGTACGT-TAMRA-3', respectively. For SATB1, the forward primer was 5'- AAATGAAGCGTGCTAAAGT-3', and the reverse primer was 5'GTTCTCCCACAGGGTTCT-3'; while the forward and reverse primers for $\beta$-actin were 5'-AAGGCCAACCGCGAGAA-3' and 5'- CCTCGTAGATGGGCACA-3', respectively.

\section{RNA extraction and qRT-PCR}

Total RNA was extracted from each tissue sample or $3 \times 10^{6}$ cells of each cell line, using TRIzol following the standard protocol. Reverse transcription was performed according to the manufacturer's instructions (TaKaRa Biotechnology Co., Japan). A $25 \mu \mathrm{l} \mathrm{PCR} \mathrm{reaction} \mathrm{mix}$ included: $3.0 \mu \mathrm{ldNTP}(2.5 \mathrm{mM}), 2.5 \mu \mathrm{lgg}^{2+}(25 \mathrm{mM}), 0.4 \mu \mathrm{l} \mathrm{Taq}$ polymerase (Fermentas, Lithuania), $2.5 \mu \mathrm{l} 10 \times$ PCR reaction buffer (TaKaRa, Japan), $0.4 \mu \mathrm{l}$ probe $(10 \mu \mathrm{M}), 0.4 \mu \mathrm{l}$ PCR forward primer $(10 \mu \mathrm{M}), 0.4 \mu \mathrm{l}$ PCR reverse primer $(10 \mu \mathrm{M}), 1 \mu \mathrm{l}$ cDNA and $14.4 \mu \mathrm{ddH}_{2} \mathrm{O}$. All PCR reactions were conducted by the two-step method on an iCycler iQ (Bio-Rad, USA) using the following conditions: denaturation at $95^{\circ} \mathrm{C}$ for $5 \mathrm{~min}$, followed by 40 cycles of amplification and quantification at $95^{\circ} \mathrm{C}$ for $20 \mathrm{~s}, 49.0^{\circ} \mathrm{C}$ for $30 \mathrm{~s}$ and $72^{\circ} \mathrm{C}$ for $30 \mathrm{~s}$. In addition, a no-template control (i.e., a negative control reaction including $\mathrm{ddH}_{2} \mathrm{O}$ instead of the DNA template) was analyzed for each run. All samples were amplified simultaneously in triplicate. The relative expression ratio (R) of a SATB1 gene was calculated based on PCR efficiency (E) and the Ct deviation of an unknown sample versus the control: $\mathrm{R}=\left(\mathrm{E}_{\mathrm{SATB} 1}\right){ }_{\mathrm{SATB} 1}{ }^{\mathrm{AC} \mathrm{t}}{ }^{\text {(control-cancer) }} /\left(\mathrm{E}_{\beta \text {-actin }}\right)$ ${ }_{\beta \text {-actin }}^{\Delta \mathrm{Ct}}$ (control-cancer) $[13]$, where $\Delta \mathrm{Ct}$ is the difference between the $\mathrm{Ct}$ values of SATB1 and $\beta$-actin, and PCR efficiency (E) is approximately 2 by calculation. The ratio of more than 1 indicated that the mRNA expression of SATB1 in rectal cancer was up-regulated.

Immunohistochemical analysis 
The tissue specimens were fixed in $4 \%$ paraformaldehyde, dehydrated and embedded in paraffin. The immunohistochemical analysis was performed on $4 \mu \mathrm{m}$-thick sections mounted onto poly-L-lysine coated glass slides. The sections were dewaxed in xylene and rehydrated in alcohol. The sections were heated in citrate buffer solution $(\mathrm{pH}$ 6.0) for $10 \mathrm{~min}$ in a microwave oven for antigen retrieval. The endogenous peroxidase activity was blocked by $3 \%$ hydrogen peroxide for 15 min. After rinsing three times in phosphate-buffered saline (PBS), the slides were treated with $10 \%$ normal goat serum at $37^{\circ} \mathrm{C}$ for $30 \mathrm{~min}$. The sections were incubated overnight with the SATB1 antibody (diluted 1:250 in 5\% goat serum in PBS; Epitomics) at $4^{\circ} \mathrm{C}$. PBS was used as a negative control. After washing three times in PBS for five min each, the sections were incubated with biotinylated goat anti-mouse immunoglobulin (ZYMED) for $40 \mathrm{~min}$ and then with horseradish peroxidase-streptavidin complex (S-A/HRP; ZYMED) for 40 min, diluted as recommended by the manufacturer. After rinsing, 3, 3'-diaminobenzidine (DAB; Abcam, Cambridge, MA, USA) was for colorimetric staining followed by hematoxylin counterstaining. Paraffin sections from a human breast carcinoma tissue were used as a positive control. For the negative control, the SATB1 antibody was substituted with PBS. To evaluate SATB1 levels, immunostained sections were scored with digital images obtained using the Olympus DD70 BX51 microscope (Olympus, Japan).

\section{Evaluation of immunohistochemical staining and scoring}

Patterns of staining, subcellular SATB1 localizations, staining intensities and percentages of SATB1 expressing cells were recorded. The staining patterns were evaluated using the immunoreactive score (IRS) proposed by Remmele and Stegner [14] in which IRS = SI (staining intensity) $\times \mathrm{PP}$ (percentage of positive cells). SI was determined as 0 , negative; 1 , weak; 2 , moderate; and 3, strong. PP was defined as 1, 0-9\% positive cells; $2,10-50 \%$ positive cells; and $3,>50 \%$ positive cells. One hundred cells were counted in each of 10 high-power visual fields (40x) from different areas of each section chosen at random for IRS evaluation, and the average IRS was calculated. The final intensity of SATB1 staining was defined as 'negative' and 'positive', corresponding to IRS values of $\leq 1$ and $>1$, respectively. The tissue sections were reviewed and scored by two researchers including a pathologist to minimize subjectivity. Staining was repeated 
in equivocal cases, and eventually consensus between the two researchers was achieved in all cases. Differences in SATB1 expression between adjacent normal and carcinoma tissues were based on final SATB1 staining.

\section{Western blotting}

Proteins were extracted with RIPA lysis buffer (KeyGEN Biotech. Co., Ltd, China) and quantified using the Bradford method. After denaturation at $95^{\circ} \mathrm{C}$ for $5 \mathrm{~min}$, equal amounts of proteins $(20 \mu \mathrm{g})$ were loaded into each well of a 10\% SDS-PAGE gel. After electrophoresis, the proteins were transferred to a polyvinylidene difluoride membrane at $100 \mathrm{~V}$ for $90 \mathrm{~min}$ (Bio-Rad, USA). The membrane was blocked with $5 \%$ skim milk for $1 \mathrm{~h}$, followed by overnight incubation at $4^{\circ} \mathrm{C}$ with primary antibody, rabbit anti-human SATB1 (diluted 1:2000; Epitomics, USA) or rabbit anti-human $\beta$-actin (diluted 1:1000; Cell Signaling Technology, USA). After washing three times with TBST (Tris-buffered saline with $0.1 \%$ Tween-20) buffer, the membrane was incubated with secondary horseradish peroxidase-conjugated anti-rabbit antibodies (diluted 1:2500; Santa Cruz Biotechnology, USA) at room temperature for $2 \mathrm{~h}$, developed with an enhanced chemiluminescence and visualized with a Multimage Light Cabinet (Alpha Innotech Corporation, USA).

\section{Statistical analysis}

Statistical analysis was carried out using SPSS version 17.0. Group-wise comparison and statistical analysis of relative mRNA expression were performed using the Relative Expression Software Tool (REST) [15]. Pearson's chi-squared $\left(\chi^{2}\right)$ test or Fisher exact test was used to analyze the correlation between SATB1 expression and clinicopathological features. $P$-values of $<$ 0.05 were considered statistically significant.

\section{Results}

\section{Demographics}


A total of 93 patients were eventually included in the study. Ages of the patients ranged from 22 to 87 years, with an average of 58.4 years, including 40 females and 53 males. In this study, the numbers of samples classified as TNM stages I + II and III + IV were 45 and 48, respectively. There were 81 patients with low grade tumors and 12 patients with high grade tumors. The number of patients with lymph node positive rectal cancer was approximately equal to that of patients with lymph node negative rectal cancer. Detailed demographic information on the patients and their clinicopathological features are listed in Table 1.

Analysis of SATB1 mRNA expression in cancerous and normal rectal samples using qRT-PCR

SATB1 mRNA was found to be expressed in both normal rectal tissue and rectal cancer specimens, but the general level of SATB1 mRNA expression in rectal cancer tissues was statistically significantly higher than that in normal mucosa $(P=0.043)$. Among the 93 rectal cancer RNA samples tested, 45 cases showed overexpression of SATB1. Major differences in the overexpression of SATB1 in rectal cancer were observed. SATB1 mRNA expression in 22 tumors were less than 5-fold higher, 2 tumors were 5-10-fold higher, 3 tumors were 10-20 times higher, and 18 tumors were more than 20-fold higher than in normal rectal tissue.

\section{Associations between SATB1 mRNA expression and clinicopathological features}

The associations between clinicopathological features and SATB1 expression in individuals with rectal cancer are summarized in Table 1. A higher prevalence of overexpressed SATB1 mRNA was found in tumors of patients with earlier onset of rectal cancer than in those diagnosed later in life ( $68.2 \%$ in cases with age at diagnosis $<50$ years $v s .42 .3 \%$ in cases $\geq 50$ years), and it was significant as compared to those with tumors underexpressing SATB1 mRNA $(P=0.033)$. Elevated expression of SATB1 mRNA was more predominant in patients with advanced lesions (T3 and T4) rather than early lesions (T1 and T2) $(P=0.029)$. Patients with cancer at advanced stages (stages III and IV) had higher SATB1 mRNA levels than those with early stage cancers (stages I and II $)(P=0.047)$. The expression of SATB1 mRNA also tended to increase in patients with high grade cancer, mucinous adenocarcinoma or positive lymph node, although these 
increases were not statistically significant. However, SATB1 mRNA overexpression was not associated with gender $(P=0.366)$, tumor size $(P=0.649)$ or serum CEA level $(P=0.737)$.

Immunohistochemical analysis of SATB1 protein expression in cancerous and normal rectal samples

Immunohistochemistry (IHC) was carried out to determine the protein expression and subcellular localization of SATB1 in the rectal cancer tissues and their normal counterparts. The representative results are shown in Fig. 1. SATB1 proteins were intensively localized in the nuclei of both normal rectal tissue and rectal cancer epithelial cells. The SATB1 protein expression was significantly different between the normal and carcinoma tissues (25.8\% and $44.1 \%$, respectively; $P=0.009)$. Moreover, the intensity of immunoreactivity was variable within the rectal cancer tissues, suggesting that the tumor cells heterogeneously expressed SATB1.

Associations between SATB1 protein expression and clinicopathological features The positive expression of SATB1 protein was markedly correlated with depth of invasion $(P=$ $0.029)$ and TNM stage of rectal cancer $(P=0.043)$, but not with patients'age $(P=0.105)$, gender ( $P=0.697)$, tumor size $(P=0.231)$, grade of differentiation $(P=0.287)$, and serum CEA levels $(P$ $=0.392$ ). Furthermore, the expression of SATB1 protein tended to be increased in patients with mucinous adenocarcinoma or positive lymph node and no statistical significance reached, although the $P$ values were extremely close to $0.05(P=0.065$ and $P=0.074$, respectively) (Table 2).

SATB1 expression in human colon carcinoma cell lines

All of the five human colon cancer cell lines tested were also SATB1-positive at the mRNA level. Furthermore, the expressions of SATB1 gene in the colon cell line KM12C and its metastatic counterparts (KM12SM and KM12L4A) were significantly higher than those in the HCT116 and SW480 cells $(P=0.001)$. Strikingly, the highly metastatic KM12SM and KM12L4A cell lines displayed higher levels of SATB1 expression compared with the poorly metastatic KM12C cell line $(P=0.001)$. The amplification curves and corresponding $\mathrm{Ct}$ values of SATB1 and $\beta$-actin 
gene in the colon carcinoma cell lines are shown in Supplementary materials. Moreover, the SATB1 mRNA and protein expressions were concordant (Fig. 2).

\section{Discussion}

SATB1 is a tissue-specific matrix association region (MAR)-binding protein that participates in chromatin higher structure packaging and tissue-specific gene expression [16]. The function of SATB1 was mainly studied in immune cells in the past decade, and it is known to play a vital role in the development and maturation of T cells [3]. SATB1 can regulate T cell gene expression by linking far distal target sequences in a cage-like network and recruiting transcription and chromatin-remodeling factors to the target genes $[3,6,17,18]$. These findings would normally relegate SATB1 as a protein of interest primarily for molecular biologists, were it not for the recent revelation by Han et al. [7] that SATB1 is aberrantly expressed in human metastatic breast cancer and likely functions to reprogram chromatin organization and transcriptional profiles of breast tumors to promote growth and metastasis. That study revealed a previously unknown involvement of SATB1 in cancer development. Therefore, the role of SATB1 in breast cancer represents a new paradigm for understanding the mechanisms of other tumor and raises the possibility that it may participate in the development and progression of other malignant tumors Subsequent studies also confirmed that elevated expressions of SATB1 in laryngeal squamous cell carcinoma and gastric cancer are significantly involved in both tumor invasion and metastasis [8-10]. Unfortunately, no study has reported to date on the relationship between SATB1 and colorectal carcinoma

The present study provided new insights into the role of SATB1 in the progression of rectal cancer. We found that high levels of SATB1 expression were closely correlated with invasive depth and TNM stage of rectal cancer, and the overexpression of SATB1 mRNA was more predominant in patients with earlier onset of rectal cancer. Our results also indicated that SATB1 expression tended to increase although not significantly in patients with mucinous adenocarcinoma or positive lymph node. To confirm these observations, we analyzed SATB1 expression in five colon cancer cell lines and found that all of them were also SATB1 positive at 
the mRNA and protein levels. Additionally, the SATB1 gene expressions in KM12C cells and their metastatic derivatives were significantly higher compared with the HCT116 and SW480 cells. We also found that the highly metastatic KM12SM and KM12L4A cell lines displayed higher levels of SATB1 compared with the poorly metastatic KM12C cell line. All these results indicated that the elevated expression of SATB1 may be a key genetic change that plays an important role in the progression of human rectal cancer.

Genetic alterations have been studied extensively during various stages of colorectal cancer progression. Therefore, it is critical to identify the altered the genes that accumulate during cancer progression, as well as those genes responsible for the acquisition of invasive and/or metastatic potential in cancer cells [19]. SATB1 was identified by Han et al. as the first protein to facilitate tumor growth and metastasis by universally remodeling the chromatin structure and transcriptional expression of many genes [7]. Thus, SATB1 was suggested to repress the activity of genes found near its DNA binding sites. However, some of the genes repressed by SATB1 are known to be upregulated by Wnt signals. In 2008, Purbey and colleagues [20] reported that the transcriptional targets of SATB1 and CtBP1 overlap, suggesting common mechanism(s) of regulation and that the involvement of SATB1 acetylation in Wnt/ $\beta$-catenin signaling in T cells. Most recently, Notani et al. [21] further established that SATB1 is involved in Th2 cell differentiation and functions downstream of the Wnt/ $\beta$-catenin signaling pathway. Because activating mutations in the Wnt/ $\beta$-catenin signaling pathway are associated with approximately $90 \%$ of CRC [22] and $\beta$-catenin, the major nuclear component of $\mathrm{Wnt} / \beta$-catenin signaling, is directly regulated by SATB1 in breast cancer and T cells, it is imperative to identified whether (and how) SATB1 and $\mathrm{Wnt} / \beta$-catenin signaling might interact in CRC in future studies. If this potential interaction is proven to be functionally significant, new drugs targeting this molecular marker and therapeutic strategies can be developed accordingly.

\section{Conclusion}

In summary, our study presents the first link between SATB1 expression and rectal cancer development. Our results also have significance implications for exploring a new pathway in the 
progression of rectal cancer. Understanding more about the role of the SATB1 gene in patients with CRC may not only help clinicians to better determine the prognosis of patients but also guide the development of agents for the treatment of advanced or metastatic CRC.

Acknowledgements This study was supported by the National Natural Science Foundation of China (No. 30830100) and Ph.D. Programs Foundation of the Ministry of Education of China (No. 20080610058). We thank Yong Liu and Yang Li for their technical assistance. 


\section{References}

1. Jemal A, Siegel R, Ward E, Murray T, Xu J, Smigal C, Thun MJ (2006) Cancer statistics, 2006. CA Cancer J Clin 56:106-130

2. Kouzarides T (1999) Histone acetylases and deacetylases in cell proliferation. Curr Opin Genet Dev 9:40-48

3. Alvarez JD, Yasui DH, Niida H, Joh T, Loh DY, Kohwi-Shigematsu T (2000) The MAR-binding protein SATB1 orchestrates temporal and spatial expression of multiple genes during T-cell development. Genes Dev 14:521-535

4. Kumar PP, Purbey PK, Sinha CK, Notani D, Limaye A, Jayani RS, Galande S (2006) Phosphorylation of SATB1, a global gene regulator, acts as a molecular switch regulating its transcriptional activity in vivo. Mol Cell 22:231-243

5. Wen J, Huang S, Rogers H, Dickinson LA, Kohwi-Shigematsu T, Noguchi CT (2005) SATB1 family protein expressed during early erythroid differentiation modifies globin gene expression. Blood 105:3330-3339

6. Cai S, Lee CC, Kohwi-Shigematsu T (2006) SATB1 packages densely looped, transcriptionally active chromatin for coordinated expression of cytokine genes. Nat Genet $38: 1278-1288$

7. Han HJ, Russo J, Kohwi Y, Kohwi-Shigematsu T (2008) SATB1 reprogrammes gene expression to promote breast tumour growth and metastasis. Nature 452:187-193

8. Zhao XD, Ji WY, Zhang W, He LX, Yang J, Liang HJ, Wang LL (2010) Overexpression of SATB1 in laryngeal squamous cell carcinoma. ORL J Otorhinolaryngol Relat Spec 72:1-5

9. Lu X, Cheng C, Zhu S, Yang Y, Zheng L, Wang G, Shu X, Wu K, Liu K, Tong Q (2010) SATB1 is an independent prognostic marker for gastric cancer in a Chinese population. Oncol Rep 24:981-987

10. Cheng C, Lu X, Wang G, Zheng L, Shu X, Zhu S, Liu K, Wu K, Tong Q (2010) Expression of SATB1 and heparanase in gastric cancer and its relationship to clinicopathologic features. APMIS 118:855-863

11. Wang S, Zhou J, Wang XY, Hao JM, Chen JZ, Zhang XM, Jin H, Liu L, Zhang YF, Liu J, Ding YQ, Li JM (2009) Down-regulated expression of SATB2 is associated with metastasis and poor prognosis in colorectal cancer. J Pathol 219:114-122 
12. Edge SB, Byrd DR, Compton CC, Fritz AG, Greene FL, Trotti A (2010) AJCC Cancer Staging Manual. 7th edn. New York: Springer, pp 143-164

13. Pfaffl MW (2001) A new mathematical model for relative quantification in real-time RT-PCR. Nucleic Acids Res 29:e45

14. Remmele W, Stegner HE (1987) Recommendation for uniform definition of an immunoreactive score (IRS) for immunohistochemical estrogen receptor detection (ER-ICA) in breast cancer tissue. Pathologe 8:138-140

15. Pfaffl MW, Horgan GW, Dempfle L (2002) Relative expression software tool (REST) real-time PCR. Nucleic Acids Res 30:e36

16. Zheng J (2008) Is SATB1 a master regulator in breast cancer growth and metastasis? Womens Health (Lond Engl) 4:329-332

17. Yasui D, Miyano M, Cai S, Varga-Weisz P, Kohwi-Shigematsu T (2002) SATB1 targets chromatin remodelling to regulate genes over long distances. Nature 419:641-645

18. Cai S, Han HJ, Kohwi-Shigematsu T (2003) Tissue-specific nuclear architecture and gene expression regulated by SATB1. Nat Genet 34:42-51

19. Yokota J (2000) Tumor progression and metastasis. Carcinogenesis 21:497-503

20. Purbey PK, Singh S, Notani D, Kumar PP, Limaye AS, Galande S (2009) Acetylation-dependent interaction of SATB1 and CtBP1 mediates transcriptional repression by SATB1. Mol Cell Biol 29:1321-1337

21. Notani D, Gottimukkala KP, Jayani RS, Limaye AS, Damle MV, Mehta S, Purbey PK, Joseph J, Galande S (2010) Global regulator SATB1 recruits $\beta$-catenin and regulates $\mathrm{TH}_{2}$ differentiation in Wnt-dependent manner. PLoS Biol 8:e1000296

22. Kongkanuntn R, Bubb VJ, Sansom OJ, Wyllie AH, Harrison DJ, Clarke AR (1999)

Dysregulated expression of $\beta$-catenin marks early neoplastic change in Apc mutant mice, but not all lesions arising in Msh2 deficient mice. Oncogene 18:7219-7225 


\section{Table 1}

Correlation of clinicopathological features of patients with rectal cancer and ratio of SATB1 mRNA expression.

\begin{tabular}{|c|c|c|c|c|}
\hline \multirow{2}{*}{$\begin{array}{l}\text { Clinicopathological } \\
\text { feature }\end{array}$} & \multirow{2}{*}{$n$} & \multicolumn{2}{|c|}{ SATB1 mRNA expression } & \multirow{2}{*}{$P$} \\
\hline & & Ratio $>1^{\mathrm{a}}$ & Ratio $\leq 1^{\mathrm{b}}$ & \\
\hline \multicolumn{5}{|l|}{ Gender } \\
\hline Male & 52 & $23(44.2)$ & $29(55.8)$ & \multirow{2}{*}{0.366} \\
\hline Female & 41 & $22(53.7)$ & $19(46.3)$ & \\
\hline \multicolumn{5}{|l|}{ Age (years) } \\
\hline$<50$ & 22 & $15(68.2)$ & $7(31.8)$ & \multirow{2}{*}{$0.033^{*}$} \\
\hline$\geq 50$ & 71 & $30(42.3)$ & $41(57.7)$ & \\
\hline Tumor size (mm) & 93 & $41.3 \pm 15.4$ & $39.5 \pm 19.4$ & 0.649 \\
\hline \multicolumn{5}{|l|}{ Depth of invasion } \\
\hline $\mathrm{T} 1+\mathrm{T} 2$ & 24 & $7(29.2)$ & $17(70.8)$ & \multirow{2}{*}{$0.029^{*}$} \\
\hline $\mathrm{T} 3+\mathrm{T} 4$ & 69 & $38(55.1)$ & $31(44.9)$ & \\
\hline \multicolumn{5}{|l|}{ TNM stage } \\
\hline I + II & 45 & $17(37.8)$ & $28(62.2)$ & \multirow{2}{*}{$0.047^{*}$} \\
\hline $\mathrm{III}+\mathrm{IV}$ & 48 & $28(58.3)$ & $20(41.7)$ & \\
\hline \multicolumn{5}{|l|}{ Tumor histology } \\
\hline Nonmucinous & 85 & $39(45.9)$ & $46(54.1)$ & \multirow{2}{*}{0.150} \\
\hline Mucinous & 8 & $6(75.0)$ & $2(25.0)$ & \\
\hline \multicolumn{5}{|l|}{$\begin{array}{l}\text { Grade of } \\
\text { differentiation }\end{array}$} \\
\hline Low & 81 & $36(44.4)$ & $45(55.6)$ & \multirow{2}{*}{0.065} \\
\hline High & 12 & $9(75.0)$ & $3(25.0)$ & \\
\hline \multicolumn{5}{|l|}{ Lymph node status } \\
\hline Positive & 47 & $26(55.3)$ & $21(44.7)$ & \multirow{2}{*}{0.176} \\
\hline Negative & 46 & $19(41.3)$ & $27(58.7)$ & \\
\hline \multicolumn{5}{|l|}{$\begin{array}{l}\text { Serum CEA level } \\
(\mathrm{ng} / \mathrm{ml})\end{array}$} \\
\hline$<3.4$ & 50 & $25(50.0)$ & $25(50.0)$ & \multirow{2}{*}{0.737} \\
\hline$\geq 3.4$ & 43 & $20(46.5)$ & $23(53.5)$ & \\
\hline
\end{tabular}

${ }^{\mathrm{a}}$ The expression of SATB1 was up-regulated.

${ }^{\mathrm{b}}$ The expression of SATB1 was down-regulated.

${ }^{*}$ Statistical significances were indicated. 


\section{Table 2}

Correlation of clinicopathological features of the patients with rectal cancer and ratio of SATB1 protein expression.

\begin{tabular}{|c|c|c|c|c|}
\hline \multirow{2}{*}{$\begin{array}{l}\text { Clinicopathological } \\
\text { feature }\end{array}$} & \multirow{2}{*}{$n$} & \multicolumn{2}{|c|}{ SATB1 protein expression } & \multirow{2}{*}{$P$} \\
\hline & & IRS $>1^{a}$ & $\mathrm{IRS} \leq 1^{\mathrm{b}}$ & \\
\hline \multicolumn{5}{|l|}{ Gender } \\
\hline Male & 52 & $22(42.3)$ & $30(57.7)$ & \multirow{2}{*}{0.697} \\
\hline Female & 41 & $19(46.3)$ & $22(53.7)$ & \\
\hline \multicolumn{5}{|l|}{ Age (years) } \\
\hline$<50$ & 22 & $13(59.1)$ & $9(40.9)$ & \multirow{2}{*}{0.105} \\
\hline$\geq 50$ & 71 & $28(39.4)$ & $43(60.6)$ & \\
\hline Tumor size (mm) & 93 & $41.9 \pm 19.3$ & $37.1 \pm 14.5$ & 0.231 \\
\hline \multicolumn{5}{|l|}{ Depth of invasion } \\
\hline $\mathrm{T} 1+\mathrm{T} 2$ & 24 & $6(25.0)$ & $18(75.0)$ & \multirow{2}{*}{$0.029^{*}$} \\
\hline $\mathrm{T} 3+\mathrm{T} 4$ & 69 & $35(50.7)$ & $34(49.3)$ & \\
\hline \multicolumn{5}{|l|}{ TNM stage } \\
\hline I + II & 45 & $15(33.3)$ & $30(66.7)$ & \multirow{2}{*}{$0.043^{*}$} \\
\hline III+IV & 48 & $26(54.2)$ & $22(45.8)$ & \\
\hline \multicolumn{5}{|l|}{ Tumor histology } \\
\hline Nonmucinous & 85 & $35(41.2)$ & $50(58.8)$ & \multirow{2}{*}{0.065} \\
\hline Mucinous & 8 & $6(75.0)$ & $2(25.0)$ & \\
\hline \multicolumn{5}{|c|}{ Grade of differentiation } \\
\hline Low & 81 & $34(42.0)$ & $47(58.0)$ & \multirow{2}{*}{0.287} \\
\hline High & 12 & $7(58.3)$ & $5(41.7)$ & \\
\hline \multicolumn{5}{|l|}{ Lymph node status } \\
\hline Positive & 47 & $25(53.2)$ & $22(46.8)$ & \multirow{2}{*}{0.074} \\
\hline Negative & 46 & $16(34.8)$ & $30(65.2)$ & \\
\hline \multicolumn{5}{|l|}{$\begin{array}{l}\text { Serum CEA level } \\
(\mathrm{ng} / \mathrm{ml})\end{array}$} \\
\hline$<3.4$ & 50 & $20(40.0)$ & $30(60.0)$ & \multirow{2}{*}{0.392} \\
\hline$\geq 3.4$ & 43 & $21(48.8)$ & $22(51.2)$ & \\
\hline
\end{tabular}

${ }^{\mathrm{a}}$ The staining of SATB1 protein was positive.

${ }^{\mathrm{b}}$ The staining of SATB1 protein was negative.

${ }^{*}$ Statistical significances were indicated. 
Fig. 1 Representative SATB1 immunohistochemical staining. a, b Positive brown staining was shown in the nuclei of rectal cancer epithelial cells and paired normal rectal tissues, respectively. c Human breast carcinoma tissues with positive staining were used as positive controls. $d$ Rectal cancer tissues incubated without primary antibody were used as negative controls. Original magnification, $\times 400$ 
Fig. 2 Differentially expressed patterns of SATB1 protein in the five colon cancer cell lines detected by Western blotting. SATB1 expression in the poorly metastatic KM12C cells was significantly lower than the highly metastatic KM12SM and KM12L4A cells and higher than the HCT116 and SW480 cells. The experiment was repeated three times. 


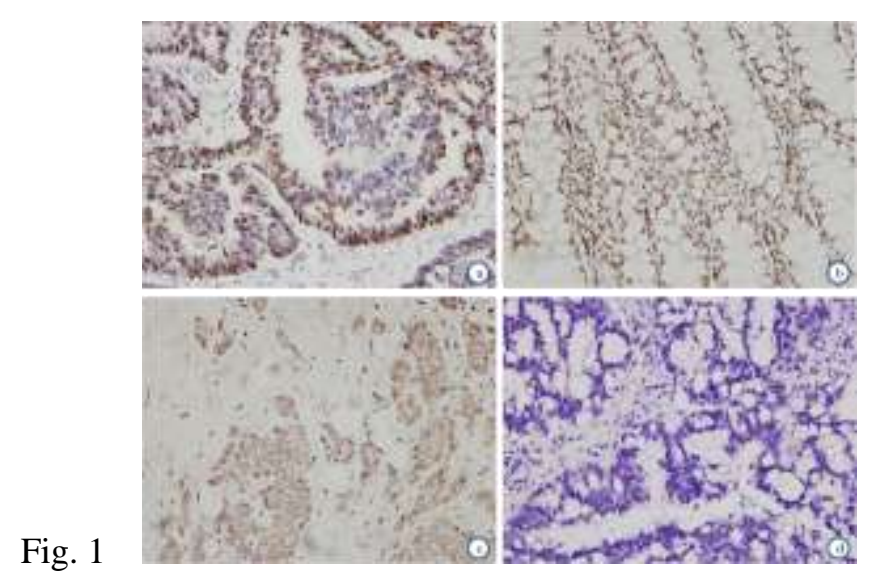


Fig. 2
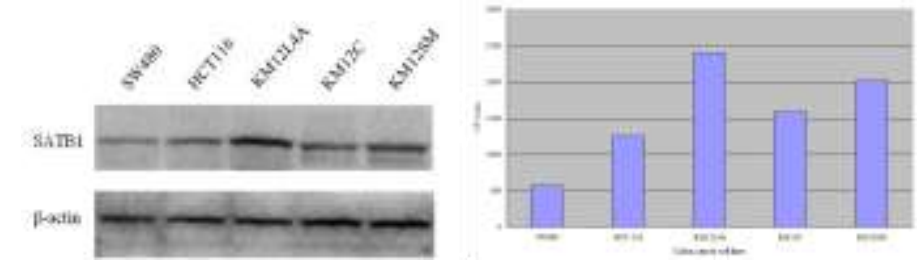
Supplementary Figure 1
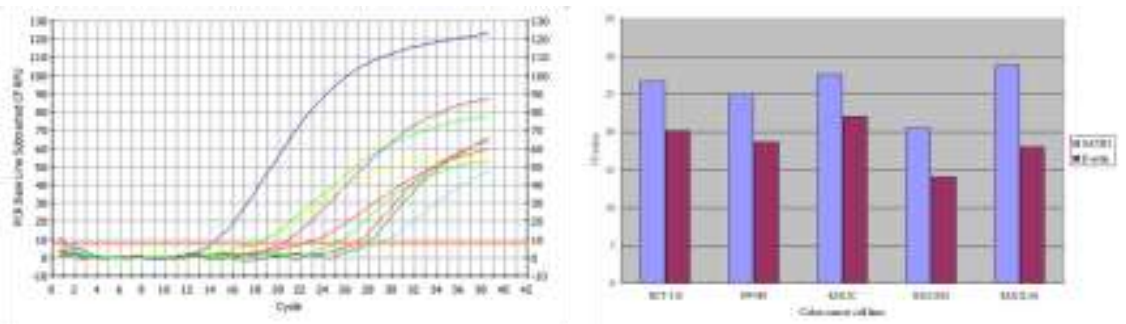